
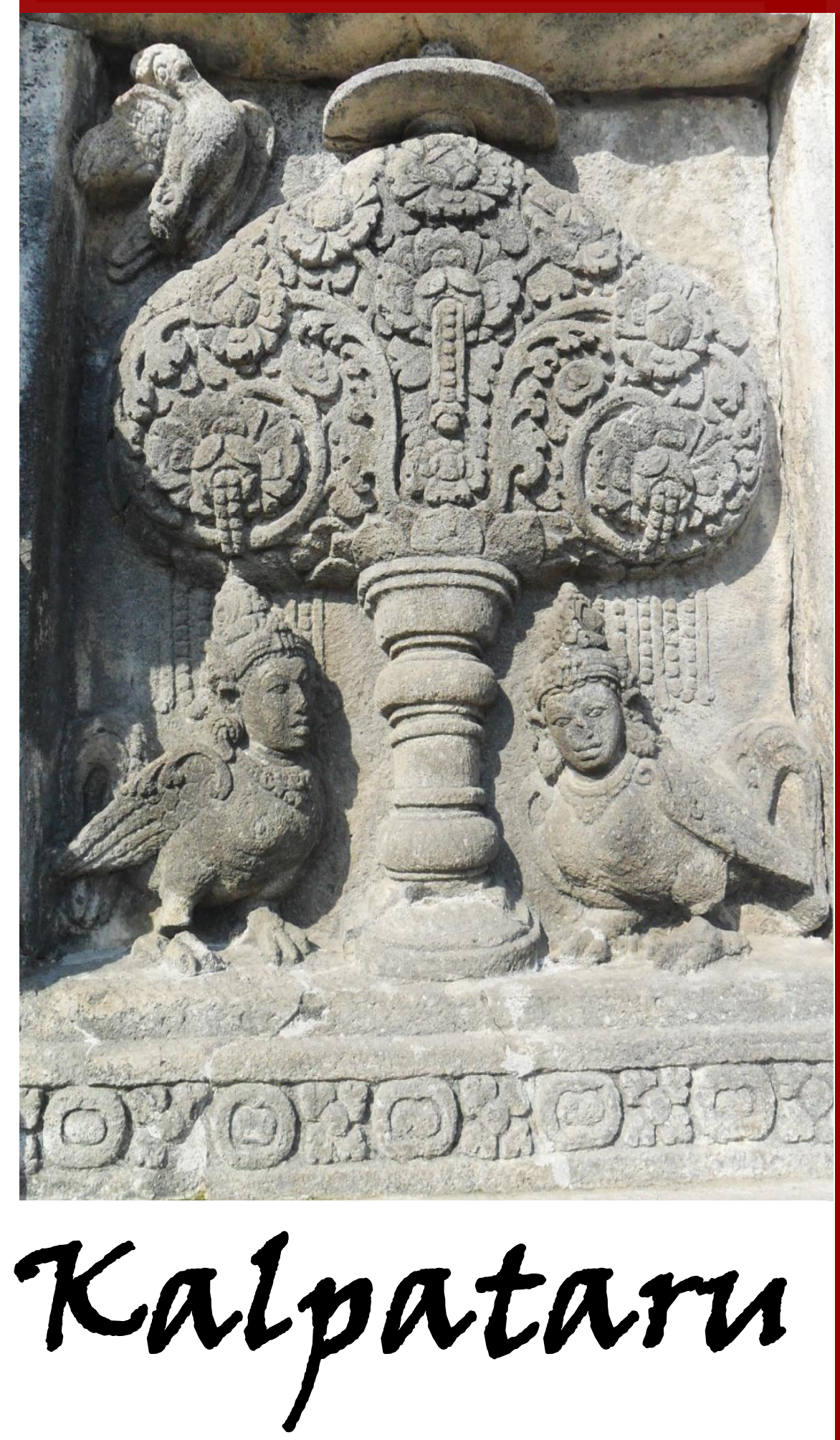

JURNAL SEJARAH DAN PEMBELAJARAN SEJARAH

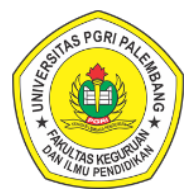

Program Studi Pendidikan Sejarah Jurusan Pendidikan IPS

Fakultas Keguruan dan IImu Pendidikan Universitas Persatuan Guru Republik Indonesia Palembang
Pengaruh Penerapan Model Project Based Learning Berbasis Video Vlog Dalam Proses Pembelajaran Sejarah Farena Adela, Nur Ahyani, Dina Sri Nindiati

Identifikasi Nilai Pedagogi Pada Pahatan Monolid Desa Jarakan Sebagai Sumber Pembelaran Sejarah Alzata Putra, Sukardi, Aan Suriadi

Nilai Sejarah Makam Puyang Ulak Laut di Pecah Pinggan Sebagai Sumber Pembelajaran Sejarah Berbasis Digital Dewi Cahya, Sukardi, Eva Dina Chairunisa

Pola Sebaran Permukiman di Kota Kayu Agung

I Made Lingga Wardana, Sukardi, Wandiyo

Peran Adam Malik Sebagai Ketua Sidang Majelis Umum PBB 1971 Rani Noviyanti

Pemanfaatan Foto dan Arsip Sebagai Sumber Pembelajaran Sejarah Riki Andi Saputro, Muhammad Fitri

Nilai-Nilai Sejarah Puyang Muara Rambang Sebagai Sumber Pelajaran Sejarah Lokal di SMA 01 Muarakuang Dwi Cahyati, Sukardi, Eva Dina Chairunisa

Pemikiran Abdul Mukti Ali Sebagai Sumber Pembelajaran Sejarah di SMA Patra Mandiri 1 Palembang Andika Merryanto Saputra, Aan Suriadi, Ahmad Zamhari

Perjuangan Hj. Rangkayo Rasuna Said Sebagai Pejuang Politik dan Pemikir Pergerakan Pada Masa Pra Kemerdekaan

Narani Agesti, Ageng Sanjaya

Nilai Sosial Religi Tradisi Manopeng Pada Masyarakat Banyiur Muhammad Fitri, Heri Susanto 


\title{
PEMIKIRAN ABDUL MUKTI ALI SEBAGAI SUMBER PEMBELAJARAN SEJARAH DI SMA PATRA MANDIRI 1 PALEMBANG
}

\author{
Andika Merryanto Saputra \\ Mahasiswa Program Studi Pendidikan Sejarah FKIP Universitas PGRI Palembang \\ Email: andikamerryantosaputra@gmail.com

\begin{abstract}
Aan Suriadi
Dosen Program Studi Pendidikan Sejarah FKIP Universitas PGRI Palembang

Email: aandesalega30@yahoo.com
\end{abstract} \\ Ahmad Zamhari \\ Dosen Program Studi Pendidikan Sejarah FKIP Universitas PGRI Palembang \\ Email: ahmadzamhari_sj@univpgri-palembang.ac.id
}

\begin{abstract}
ABSTRAK
Tujuan penelitian ini adalah menerapkan metodologi penulisan sejarah untuk mengkaji secara mendalam. Menjadi bahan rujukan, melatih dan meningkatkan daya pikir dalam penulisan sejarah. Penelitian ini menggunakan penulisan studi kepustakaan, yaitu memanfaatkan sumber perpustakaan untuk memperoleh data-data penelitian. Dengan studi kepustakaan membatasi kegiatan penelitian hanya pada bahan-bahan koleksi perpustakaan saja tanpa harus melakukan penelitian lapangan. Adapun langkah-langkah yang dilakukan dalam penulisan ini terdiri dari heuristik, kritik sumber, interpretasi, historiografi. Dalam penulisan penelitian ini menyimpulkan bahwa. 1) Konsep pemikiran pendidikan Abdul Mukti Ali dapat disimpulkan bahwa peran agama dalam pendidikan menjadi bagian teratas untuk membangun Indonesia. Dalam memahami agama Abdul Mukti Ali juga mencetuskan ilmu metodologi agama yang berusaha menghubungkan tujuan dibentuknya manusia yaitu sebagai hamba dan pemimpin dengan tujuan pendidikan. 2) Kontribusi pemikiran Abdul Mukti Ali dalam menegakan antar umat beragama di Indonesia, menyentuh dua aspek, yakni aspek keilmuan dan relasi sosial. Pada aspek keilmuan ditandai dengan tampilnya perbandingan agama sebagai ilmu pengetahuan yang begitu penting untuk memahami dan menyikapi keragaman agama. 3) Abdul Mukti Ali menjadi menteri pada masa Orde Baru yaitu pada kebinet Pembangunan II dengan transisi waktu 28 Maret 1973 sampai 29 Maret 1978. Pada masa itu, banyak perubahan yang telah dilakukan dan itu memberikan dampak besar terhadap pendewasaan berfikir masyarakat Indonesia.
\end{abstract}

Kata Kunci: Pemikiran Pendidikan, Abdul Mukti Ali, Kontribusi Terhadap Kerukunan Antar Umat Beragama

\section{A. PENDAHULUAN}

Arus global menimbulkan dampak menyeluruh ke dalam aspek kehidupan, termasuk ranah pendidikan, dimana semua negara berkompetisi untuk menghasilkan generasi muda yang unggul dan berpartisipasi pendidikan juga menjadi sebuah potensi utama dari suatu negara, karena dapat dipastikan jika sebuah negara memiliki manajemen pendidikan yang bagus, maka negara tersebut pasti termasuk dalam kategori negara maju.
Menurut Oemar Malik (2011:3), pendidikan mengajarkan manusia untuk memiliki moral, sebagai pengontrol kehidupannya terutama ketika mereka hidup bermasyarakat. Karena pendidikan adalah suatu proses dalam rangka mempengaruhi peserta didik supaya mampu menyesuiakan diri sebaik mungkin dengan lingkungannya, dengan demikian akan menimbulkan perubahan dalam dirinya yang memungkinkan untuk berfungsi secara memadai dalam kehidupan masyarakat. 


\section{Kalpataru, Volume 7, Nomor 2, Desember 2021 (142-152)}

Terjadinya perbedaan pendapat mengenai aliran teknologi dalam umat telah disampaikan oleh Nabi SAW dalam hadist yang artinya, "Umatku akan terpecah menjadi tujuh puluh tiga golongan, tetapi hanya satu golongan yang akan selamat, golongan yang lain akan binasa". Tentu timbul pertanyaan golongan manakah yang selamat itu? Rasulullah tidak memberikan jawaban dengan menunjuk golongan tertentu tetapi dengan memberikan kriteria golongan yang selamat tersebut, "(yaitu) orang-orang yang mengikuti sunnah dan aljama'ah" (HR. Tirmidzi, Kitsbul Imam).

Riwayat hadist di atas memberikan gambaran umum apa yang selalu terjadi di dalam umat Islam. Klaim kebenaran, hak kebenaran dan hak pemegang kebenaran sejati muncul dari setiap golongan dan sering kali dikuti dengan pertumpahan darah. Perenungan yang mendalam mengenai teks hadist dan fenomena yang terjadi seharusnya memberikan jalan keluar dari konflik yang berlarut-larut hingga kini. Secara faktual hadist tersebut tidak menunjuk hidung dengan menunjuk golongan yang mana yang terselamatkan itu.

Dengan hal ini pendidikan Islam memiliki ruang lingkup yang luas. Disebutkan dalam beberapa poin di antaranya adalah 1) Setiap proses perubahan menuju ke arah kemajuan dan perkembangan berdasarkan pada ruh ajaran Islam. 2) Perpaduan antar pendidikan jasmani, akal (intelektual), mental, perasaan (emosi), dan rohani (spiritual). 3) Keseimbangan antara jasmani-rohani, keimanan-ketaqwaan, pikir-dzikir, ilmiah-amaliyah, material-spritual, individual-sosial, dan dunia-akhirat. 4) Realisasi dwi fungsi manusia, yaitu peribadatan sebagai hamba Allah (Adullah) untuk menghambakan diri semata-mata kepada Allah dan fungsi kekhilafahan sebagai khalifah Allah (khalifatullah) yang memberi tugas untuk menguasai, memelihara, memanfaatkan, melestarikan dan memakmurkan alam semesta (rahmatallil'alamin) (M. Roqib, 2009:22).

Jika kita melihat realita pendidikan Islam saat ini, sungguh jauh dari kejayaan pada masa lampau. Dimana pendidikan Islam sempat menjadi puncak peradaban pada masa khalifah Harun Ar-Rasyid. Mampu menjadikan Baghdad sebagai kota pendidikan dunia yang terdapat sebuah perpustakan yang menjadi referensi pengetahuan dunia pada masa itu.

Menelusuri salah satu tokoh pendidikan Islam di era Orde Baru, yang memiliki banyak peranan penting di dunia pendidikan Indonesia, terutama masalah pluralisme, modernisasi politik keagamaan, faham Islam Timur Tengah dan lain sebagainya. Yang intinya beliau adalah pemikir pendidikan Islam dengan gagasan yang filosofis pula. Beliau adalah Abdul Mukti Ali

Dalam sebuah pemikiranya, Abdul Mukti Ali memberikan perombakan dalam dunia pendidikan Islam, yaitu dengan memprakarsai pendidikan pesantren, Madrasah Ibtidaiyyah, Tsanawiyyah dan Aliyah serta sekolah agama lainnya untuk bernaung dalam lembaga Departemen Agama pada masa itu, akan tetapi terkadang terjadi sebuah perbedaan pendapat, dimana Departemen Agama seolah berdiri sendiri dan bersaing dengan Departemen Pendidikan Nasional seolah ada dualisme pendidikan di dalam satu negara pada saat itu.

Abdul Mukti Ali merupakan tokoh penting dalam dunia pendidikan Islam di Indonesia, beliau juga penggagas pluralisme di Indonesia. Pluralisme sebenarnya bukan berarti kita mempercayai kepercayaan agama lain, akan tetapi kita menghargai penganut dan mencari cara bagaimana untuk bisa hidup bersama di dalam satu negara Indonesia.

Beliau juga termasuk salah satu tokoh yang sangat mengunggulkan model pendidikan di pesantren. Karena menurutnya sistem weton dan sorongan merupakan sebuah pembelajaran yang efektif. Di pesantren juga sangat diwajibkan kepada semua santri untuk memiliki sikap tawadhu' kepada kyai dan para ustadz. Karena dalam sebuah pembelajaran, menghormati seorang guru menjadi sebuah kewajiban (Masdar Hilmi, 2005:16).

Lahirlah sebuah kurikulum baru yang diharapkan dapat merubah wajah pendidikan Indonesia, yang sebelumnya terlalu fokus pada materi dan teori belaka, lalu dengan disusunnya kurikulum baru ini bertujuan untuk mengembangkan kompetensi yang utuh antara sikap, keterampilan dan pengetahuan. Kurikulum ini adalah Kurikulum 2013.

Sempat menjadi perbincangan hangat di dunia pendidikan Indonesia, dimana terdapat 
perbedaan yang signifikan. Perbedaan ini menuntut para pengajar untuk lebih kreatif dalam menyampaikan materi, para guru juga harus bisa menjadi teladan atau contoh bagi para muridnya, karena Kurikulum 2013 ini juga mendapat sebutan sebagai kurikulum pengembangan karakter.

Namun di tahun pelajaran 2015/2016 kurikulum ini mulai diresmikan kembali dan secara perlahan mulai diimplikasikan pada pembelajaran di sekolah-sekolah. Karena di nilai kurikulum ini sangat berpotensi untuk mengembangkan peserta didik menjadi generasi yang tak hanya pintar masalah pengetahuan namun juga santun dalam perilaku, seolah menggambarkan karakter Bangsa Indonesia.

Berdasarkan permasalahan di atas peneliti tertarik untuk mengkaji tentang Pemikiran Abdul Mukti Ali Sebagai Sumber Pembelajaran Sejarah di SMA Patra Mandiri 1 Palembang.

\section{B. METODE PENELITIAN}

Dalam penelitian ini menggunakan metode penelitian Deskriptif Kualitatif, yang menggunakan cara mengumpulkan sumbersumber secara sistematis dan menggunakan sumber data secara mendalam. Penelitian Deskriptif Kualitatif diuraikan dengan kata-kata menurut responden, apa adanya sesuai dengan pertanyaan penelitiannya, kemudian dianalisis dengan kata-kata apa yang melatarbelakangi responden berprilaku (berpikir, berprasaan, dan bertindak) seperti itu tidak seperti lainnya, direduksi, ditriangulasi, disimpulkan (diberi makna oleh peneliti), dan diverifikasi (dikonsultasikan kembali kepada responden dan teman sejawat). Mengacu pada definisi tersebut, maka dalam penelitian ini akan dijelaskan pemikiran pendidikan Abdul Mukti Ali dan kontribusinya terhadap kerukunan umat beragama pada tahun 1923-2004. Adapun teknik pengumpulan data peneitian ini adalah sebagai berikut:

1. Observasi

Teknik observasi atau pemahaman materi adalah teknik pengumpulan data dengan cara memberikan pertanyaan, pemberian tugas, dan tanya jawab. Observasi adalah dasar semua ilmu pengetahuan para ilmu yang bekerja berdasarkan data, yaitu fakta mengenai dunia kenyataan yang diperoleh melalui observasi.

2. Dokumentasi

Merupakan catatan peristiwa yang sudah berlalu yang berbentuk tulisan, gambar, atau karya monumental dari seseorang. Studi dokumen merupakan pelengkap dari penggunaan metode observasi dan wawancara. Hasil penelitian akan lebih dapat dipercaya jika didukung oleh dokumen. Teknik dokumentasi digunakan untuk mengumpulkan data dari sumber noninsani. Sumber ini terdiri dari dokumen dan rekaman. Mengartikan rekaman sebagai setiap tulisan atau pertanyaan yang dipersiapkan oleh dan untuk individual atau organisasi dengan tujuan membuktikan adanya suatu peristiwa (Sugiyono, 2017:82).

3. Studi Pustaka

Studi kepustakaan merupakan kajian teoritis, referensi serta literatur ilmiah lainnya yang berkaitan dengan budaya, nilai dan norma yang berkembang pada situasi sosial yang diteliti (Sugiyono, 2012), dalam (T \& Purwoko, 2017:4).

\section{HASIL DAN PEMBAHASAN}

Pemikiran Pendidikan Islam Abdul Mukti Ali

Dalam konteks keilmuan atau studi agama, Abdul Mukti Ali mengembangkan sebuah pendekatan yang memadukan antara normatif dan empiris untuk memahami agama yang disebut scientific cum doctrinaire. Pendekatan scientific cum doctrine yang ditawarkan Abdul Mukti Ali harapannya, agar metode ilmiah ini dapat dijadikan sebagai alat untuk memahami suatu agama. Yang secara harfiah pendekatan ini terdiri dari dua aspek penting yaitu, scientific dan doctrine. Scientific memiliki makna bersifat ilmiah dan doctrine dimaknai sebagai suatu ajaran atau doktrin. Dengan kata lain pendekatan ini, menerapkan metode ilmiah yang disatukan dengan doktrin atau ajaran-ajaran yang terkandung dalam suatu agama, khususnya dalam studi Islam.

Mengkaji keilmuan menurut Abdul Mukti Ali dengan pendekatan scientific cum dotrinaire 
ini harapannya dapat memfungsikan tujuan dari studi Islam yang menurut Abdul Mukti Ali ada 4 fungsi yang akan didapat yaitu: (1) lembaga agama, yaitu badan yang berfungsi melakukan tugas agama, (2) hubungan agama, meliputi hubungan antara individu atau kelompok intern agama sendiri atau antar berbagai agama, (3) fungsi agama, yaitu sejauh mana agama mempengaruhi hidup dan kehidupan individu atau masyarakat, dan (4) teks agama (bahanbahan tertulis tentang agama) dan dokumen agama (segala sesuatu baik tulisan, foto, patung, gedung dan sebagainya yang bisa memberikan informasi tentang agama) (Abdul Mukti Ali, 1991:33-34).

Dalam konteks kemanusiaan, Abdul Mukti Ali berhasil memposisikan agama dalam kaitannya dengan pembangunan nasional yang ditandai masuknya pembangunan bidang agama dalam Garis Besar Haluan Negara (GBHN) yang kemudian dikenal istilah "pembangunan manusia seutuhnya". Sehingga umat beragama dapat berperan aktif dalam pembangunan Indonesia (Singgih Basuki, 2013:26). Abdul Mukti Ali menekankan bahwa untuk mewujudkan hubungan sosial yang harmonis, maka penting membudayakan dan melaksanakan dialog antaragama, dengan harapan bahwa akan menumbuhkan toleransi dalam hubungan antarumat beragama di Indonesia yang sangat plural. Lebih lanjut Abdul Mukti Ali menjelaskan bahwa dialog diadakan bukan semata-mata untuk dialog itu sendiri melainkan untuk meningkatkan keharmonisan dan kesejahteraan hidup bangsa Indonesia. (Singgih Basuki, 2013:260).

Berangkat dari fungsi pokok agama yang dikonsepkan Abdul Mukti Ali adalah untuk mengintegrasikan hidup dengan keikhlasan dan kesungguhan seseorang dalam memeluk agama yang diyakini untuk hidup menjadi manusia yang bermakna. Sedangkan kaitannya dengan dua peran agama dalam pembangunan nasional padalah:

1. Agama memberikan dasar niat atau motivasi bagi pembangunan. Artinya, orang yang melaksanakan pembangunan adalah karena diperintah oleh agama untuk membangun umatnya sehingga memperoleh kemajuan dan kehidupan yang lebih baik sehingga memperoleh kesejahteraan sebagaimana yang dicitacitakan bersama.

2. Mengajarkan tujuan pembangunan. Bagi umat beragama, tujuan pembangunan adalah untuk kepentingan umat manusia, bukan untuk kehancuran umat manusia.

Abdul Mukti Ali menginginkan masyarakat Islam sebagaimana waktu puncaknya pada zaman klasik, yaitu masyarakat yang memeluk agama Islam penuh penghargaan, memberikan keberanian, kehormatan, dan keteguhan pada manusia dalam menghadapi kehidupan yang penuh tantangan, serta memberikan kebaikan kepada seluruh manusia dan alam semesta (Singgih Basuki, 2013:123).

Untuk konteks kebangsaan, kondisi bangsa Indonesia yang pluralistik serta rentan terhadap konflik antar agama, ia mengemukakan konsep kerukunan antar umat beragama dengan prinsip agree in disagreement. Dengan kata lain ia berusaha melakukan pendekatan sosio historis atau empiris yang dipadukan dengan normatifdoktriner (Abdul Mukti Ali, 1996:75).

Jadi dalam pandangan Abdul Mukti Ali, agama, masyarakat dan pembangunan saling terintegrasi satu sama lain. Agama memberikan dorongan motivasi dan tujuan bagi pembangunan masyarakat di Indonesia dan untuk kepentingan umat manusia. Ikhtisar manusia Indonesia untuk mengadakan perubahan, perbaikan, peningkatan mutu serta kualitas kehidupan bangsa yang dilakukan secara sadar, berencana, terarah dan menyeluruh. Dengan demikian masyarakat beragama di Indonesia mempunyai dharma bhakti dalam usaha membentuk masyarakat baru.

\section{Konsep Pendidikan Untuk Pembangunan}

Selain fokus pada konsep agama dan masyarakat, Abdul Mukti Ali juga mempunyai gagasan tentang pembangunan pendidikan di Indonesia. Hal ini dapat dilihat dari bagaimana ia peduli terhadap perkembangan pesantren, madrasah dan sistem pendidikan di perguruan tinggi khususnya IAIN di seluruh Indonesia. Pesantren dalam pandangan Abdul Mukti Ali 
sebagai lembaga pendidikan Islam. Pengetahuan-pengetahuan yang berhubungan dengan agama Islam diharapkan diperoleh dari pondok pesantren itu. Pondok pesantren adalah tempat untuk menyeleksi calon-calon ulama dan kyai (Abdul Mukti Ali, 1998:15).

Berangkat dari konsep pesantren dan madrasah, maka pada tataran IAIN dalam harapan beliau lebih kepada mengintegrasikan pengajaran pendidikan Islam dan umum. Mahasiswa disadarkan akan perannya di masa akan datang. Untuk itu perlu ditanamkan prinsip perubahan, berpikir kritis, sadar akan pertumbuhan dan perkembangan pribadi, ditanamkan disiplin intelektual dan lainnya (Singggih Basuki, 2013). Adapun kebijakan yang diambil oleh Abdul Mukti Ali adalah:

1. Kebijakan tentang pembenahan lembaga pendidikan Islam. Hasilnya sebagai tertuang dalam Surat Keputusan Bersama (SKB) tiga menteri yaitu (1) ijazah madrasah dalam semua jenjang mempunyai nilai yang sama dengan ijazah sekolah umum, (2) agar lulusan madrasah dapat melanjutkan ke sekolah umum setingkat atau lebih atas, (3) siswa madrasah bisa pindah ke sekolah umum (Abdul Mukti Ali, 1976:17).

2. Kebijakan tentang modernisasi lembaga pesantren. Hal ini dihasilkan melalui SKB Menteri Agama dan Pertanian No. $34 \mathrm{~A}$ tahun 1972 mengadakan pembinaan pondok pesantren dalam bidang pertanian dan perikanan.

3. Kebijakan tentang pembenahan IAIN. IAIN yang tadi berjumlah 112 menjadi 13 yang diakui dan diberi izin beroperasi.

4. Kebijakan tentang peningkatan mutu IAIN. Mengirim tenaga pengajar ke luar negeri antaranya Timur Tengah, Amerika Serikat, Kanada dan Belanda (Abuddin Nata, 2012).

\section{Tujuan Pendidikan untuk Pembangunan}

Tujuan pendidikan agama di pesantren, madrasah dan universitas dalam pandangan guru besar Abdul Mukti Ali sebagaimana telah dipaparkan di atas bahwa ia menginginkan pendidikan yang terintegrasi antara pendidikan agama dan umum.
Di lembaga pesantren sendiri tetap memakai kurikulum sebagai madrasah. Hanya saja pengelompokan materi bisa dikembangkan sesuai kebijakan masing-masing pesantren. Sebagai contoh Al-Qur'an dan Hadist dikembangkan menjadi IImu Tajwid, Tafsir, dan ulum Al-Qur'an. Bahasa Arab dikembangkan ke dalam Nahwu, Shorof dan lainnya. Pada lembaga pesantren ini usaha Abdul Mukti Ali untuk memajukan pendidikan pesantren dengan memasukkan nilai pendidikan umum, pendidikan kewirausahaan, pertanian, kepramukaan sebagai usaha untuk memajukan kualitas lulusan pesantren.

Untuk di Perguruan Tinggi Umum lima aspek pokok PAl digabung dalam satu bidang studi Pendidikan Agama Islam. Sedangkan untuk Perguruan Tinggi Agama Islam kelima aspek tersebut dikembangkan sesuai fakultas dan jurusannya. Yang pada intinya sesuai dengan Permendiknas RI No. 23 Tahun 2006. Dalam peningkatan mutu tenaga pengajar diatur dalam Undang-Undang Guru dan Dosen No. 14 Tahun 2005. Dalam pandangan Abdul Mukti Ali bahwa tenaga pendidik perlu mengembangkan kemampuan diri dalam intelektualitas. Hal ini sebagaimana telah diupayakannya adanya penertiban sistem di lingkungan IAIN di Indonesia. Khususnya di IAIN Sunan Kalijaga, ia membentuk forum diskusi dosen tetap, pengiriman dosen ke luar negeri, peningkatan bahasa, peminatan ilmu dan pemahaman metode penelitian ilmu Islam dan lainnya.

\section{Kontribusi Abdul Mukti Ali Terhadap Kerukunan antar Umat Islam Mengenal Abdul Mukti Ali dan Gagasannya Terhadap Kerukunan antar Umat Agama}

Abdul Mukti Ali dikenal sebaga sosok intelektual muslim yang visioner, pluralis, disiplin serta sangat menghargai ilmu. Abdul Mukti Ali dilahirkan dari keluarga yang cukup mapan, ayahnya bernama Idris. Setelah kembali menunaikan ibadah haji nama ayahnya ditukar menjadi $\mathrm{H}$. Abu Ali, merupakan seorang yang terjun dalam dunia bisnis tembakau juga pribadi yang kerja keras dan gigih. Sedangkan ibunya bernama Muti'ah, dan setelah menunaikan ibadah haji ditukar menjadi Hj. Khadidjah, selain menjadi ibu rumah tangga ia juga ikut terjun 


\section{Kalpataru, Volume 7, Nomor 2, Desember 2021 (142-152)}

dalam bisnis kain. Dalam kemampunan keluarganya Boedjono nama kecil ayahnya. Abdul Mukti Ali dilahirkan dan dibesarkan. Pemilik 6 saudara ini lahir di Cepu, Blora, Jawa Tengah 23 Agustus 1923.

Sebagai santri, komitmen keislaman Abdul Mukti Ali tidak perlu diragukan lagi. Latar belakang lingkungan pendidikan asalnya adalah kaum santri dalam arti sesungguhnya. Abdul Mukti Ali belajar Islam di pondok pesantren Termas, kemudian dengan naluri akademik yang tinggi Abdul Mukti Ali mendaftar menjadi mahasiswa di STTI (Sekolah Tinggi Islam) Yogyakarta, selajutnya Abdul Mukti Ali belajar di Karchi Pakistan. Dan pada tahun 1955 Abdul Mukti Ali terdaftar sebagai mahasiswa di Institute of Islamic Studies, Mc. Gill University, Montreal, Kanada, mengambil spesialis IImu Perbandingan Agama. Dari sinilah, pada kenyataannya sangat mempengaruhi perkembangan pemikiran Abdul Mukti Ali dalam setiap wacana keilmuan yang dibahas, karena model pengkajian Islam di Mc. Gill University dengan menggunakan pendekatan sistematis, rasional, dan holistik, baik ditinjau dari segi ajaran, sejarah, maupun peradabannya. Mengenai model pendekatan di atas, yang melatarbelakangi paradigma berpikir. Abdul Mukti Ali memberikan pernyataan sebagai berkut:

"Pendekatan seperti ini juga dilakukan oleh $\mathrm{H}$. Mas Mansur ketika mengajar agama Islam di sekolah Tinggi Islam Jakarta tahun 1945. Ketika mengajar tafsir Al-Quran, salah satu ayat diuraikan dari segi bahasa, kemudian ditafsirkan dari segi filsafat, sejarah, hukum, ekonomi, sosial, politik sesuai dengan situasi dan kondisi akhir penjajahan Jepang saat itu. Invasi pendekatan Islam seperti ini belum banyak dilakukan di Perguruan Tinggi Islam Indonesia. Tentu dengan semangat yang kuat, penting untuk memperkenalkan pendekatan empiris atau sosio-historis seperti itu kepada masyarakat muslim di Indonesia sebagai upaya mengkaji khazanah pemikiran Islam relevan dan konteks masyarakat Indonesia saat ini dan masa datang" (Abdul Mukti Ali, 1996:23).
Salah satu pengalaman Abdul Mukti Ali yang bermanfaat untuk diketengahkan di sini. Saat ia mengikuti konspirasi-konspirasi agama tingkat internasional. Diantaranya ialah Kongres Sejarah Agama di IX di Tokyo yang diadakan pada tahun 1958, dialog antar agama yang diadakan di Beirut pada tahun 1970, (Dialouge Between Men of Living Faiths, Bairut: 1970) serta konspirasi yang dilakukan di Tokyo pada tahun 1977, mengenai Agama dan Perdamian (World Conference on Religion an Peace).

Karakter Abdul Mukti Ali yang menonjol ketika menyampaikan ide dan pemikirannya adalah tegas namun tetap santun, bersedia menghargai pendapat orang lain, tidak konfrontatif dengan pihak yang menolak idenya, cenderung mencari kompromi atau jalan tengah atas pandangan atau paham yang berbeda serta tidak proaktif. Ketika Abdul Mukti Ali memangku jabatan Menteri Agama, beberapa analisis menyatakan, ditunjukannya Abdul Mukti Ali untuk memimpin Departeman Agama itu dimaksudkan sebagai langkah Orde Baru untuk mengadakan restrukturisasi dan reorintasi kebijakan. Dengan keahliannya dibidang ilmu agama serta perhatiannya dalam berbagai forum dialog antarumat beragama, Abdul Mukti Ali dianggap sebagai orang yang paling berkompeten.

Abdul Mukti Ali berpandangan bahwa perbedaan pemikiran, agama, ras, suku, bahasa dan budaya harus dijadikan sebagai pedoman kebersamaan dalam kehidupan bermasyarakat. Di tengah perbedaan tersebut, semua kalangan harus menghargai dan menerima pluralitas sebagai kenyataan sosial. Hal ini yang menurut Abdul Mukti Ali sangat jarang dilakukan oleh masyarakat Indonesia. Berdasarkan argumentasi tersebut, Abdul Mukti Ali secara intensif mengembangkan IImu Perbandingan Agama di Indonesia, sebagai sarana keilmuan untuk memunculkan perbandingan Agama di Indonesia, sebagai sarana keilmuan untuk memunculkan sikap yang inklusif, sesuai dengan istilah Abdul Mukti Ali Agree in Disagreement. Di samping itu Abdul Mukti Ali dengan penuh semangat untuk membudayakan dialog antarumat beragama, yang diharapkan mampu untuk memantapkan keharmonisan sosial. Untuk itu, kontribusi pemikiran Abdul 


\section{Kalpataru, Volume 7, Nomor 2, Desember 2021 (142-152)}

Mukti Ali yang senantiasa konsisten dalam menegakkan kerukunan antarumat beragama di Indonesa, paling tidak menyentuh dua aspek, yakni aspek keilmuan dan reaksi sosial.

\section{Aspek Keilmuan}

Abdul Mukti Ali memperkenalkan dan mengembangkan disiplin IImu Perbandingan Agama. Obsesinya yang begitu mulia dalam mengembangkan IImu Perbandingan Agama di IAIN adalah dalam rangka membangkitkan dialog antaragama untuk menghilangkan kecurigaan serta mencari titik temu dari perbedaan yang ada. Dengan kata lain, dialog antaragama yang hakiki harus berangkat dari etos saling menghargai, pandangan humanisme unversal yang benar-benar menghargai kemanusiaan, persamaan martabat umat manusia, menghapuskan egoisme, kesepakatan untuk menerima kebenaran dari pihak lain tanpa tendensi meremehkan atau mendistoris. Dengan demikian, akan terjadi integrasi antarumat yang saling menyadari eksistensi dan menyelamatkan dunia dari perpecahan. Sedemikian pentingnya disiplin IImu Perbandingan Agama tersebut. Sehingga Abdul Mukti Ali memberikan pernyataan yang cukup mengesankan sebagai berikut:

"Sebuah cabang ilmu pengetahuan yang berusaha untuk memahami gejala-gejala dari pada suatu kepercayaan dalam hubungannya dengan agama-agama lain. Pemahamaan ini meliputi persamaan, juga perbedaan. Dari pembahasan yang demikian itu, maka struktur yang asasi daripada pengalaman keagamaan dari pada hidup manusia dan pentingnya bagi hidup dan kehidupan orang itu akan dipelajari dan dinilai" (Abdul Mukti Ali, 1991:15).

Peranan agama tidak bisa dipandang sebelah mata dalam melahirkan integritas umat beragam dan hubungan sosial. Agama menempati tempat yang sangat penting dalam kehidupan manusia, khususnya di Indonesia yang dikenal sebagai masyarakat yang relegius. Pluralitas agama di kawasan ini ditandai dengan keragamaan agama yang ditemukan dan sekaligus diterima agama diakui, yaitu Islam. Kristen, Khatolik, Hindu, Budha, dan Konghucu diajukan sebagai salah satu bagian dari agamaagama mendapat legitimasi formal untuk hidup berdampingan dengan agama-agama tersebut. Kenyataan pluralitas agama Indonesia menujukan adanya dinamisasi sekaligus problematik yang dihadapi bangsa Indonesia untuk hidup berdampingan dalam kebersamaan. Maka dalam hal memahami perbedaan agama misalnya, sikap seseorang tidak berhenti pada pemahaman secara formal. Melainkan harus dipahami sebagai sebuah kepercayaan dan merupakan kenyataan sosial beragama, sehingga akan bersikap toleran kepada pemeluk agama lain untuk itu, rasa kesadaranlah yang mampu memberikan solusi dari diri manusia dalam kehidupan beragama.

Kaitannya dengan ilmu perbandingan agama bahwa ilmu ini berusaha untuk memahami semua aspek-aspek yang diperoleh dari kajian sejarah agama kemudian dengan serius menghubungkan atau membandingkan satu agama dengan agama lainnya utuk mencapai dan menentukan struktur yang fundamental dari pengalaman-pengalaman maupun konsepsi-konsepsi dengan memilih dan menganalisa persamaan dan perbedaan antara agama-agama itu. Perbandingan agama membandingkan antara agama dan metodenya untuk mencapai suatu tujuan. Maka, perbandingan agama merupakan cabang ilmu pengetahuan yang berusaha menyelediki serta memahami aspek atau sikap keagamaan dari suatu kepercayaan, dalam hubungannya dengan agama-agama lain meliputi persamaan dan perbedaannya. Tentu kenyataan tersebut ditemukan dalam masyarakat yang pluralistik.

Berdasarkan penjelasan di atas, mengenai urgensi Ilmu Perbandingan Agama di tengah-tengah kehidupan yang begitu plural, barangkali untuk mengantisipasi atau meminimalisir potensi-potensi konflik antar umat beragama di Indonesia, dirasa perlu untuk membumisasikan gagasan-gagasan cemerlang Abdul Mukti Ali. Sebagai seorang intelektual yang sangat peduli dengan kerukunan hidup antarumat beragama di Indonesia yang pluralistik, Abdul Mukti Ali memberikan konsep Agree in Disagreement, dalam konteks situasi dan kondisi historis bangsa yang sering terjadi ketegangan dan konflik, serta tatanan harmoni 
di kalangan umat beragama di Indonesia yang sering mangalami pasang surut, maka diperlukan suatu prinsip yang memunculkan sikap mengahargai dan menghormati terhadap semua perbedaan-perbedaan yang ada. Bahkan Amin Abdullah menyebut bahwa konsep Agree in Disagreement, yang dikemukakan Abdul Mukti Ali tersebut sangat Qur'anik dan bernilai pluralistik.

\section{Relasi Sosial}

Abdul Mukti Ali menambahkan bahwa untuk mewujudkan hubungan sosial yang harmonis, maka penting membudayakan dan melaksanakan dialog antaragama, dengan harapan bahwa akan menumbuhkan toleransi dalam hubungan antarumat beragama di Indonesia yang sangat plural. Abdul Mukti Ali menjelaskan bahwa dialog diadakan bukan semata-mata untuk dialog itu sendiri melainkan untuk meningkatkan keharmonisan dan kesejahteraan hidup bangsa Indonesia.

Perjuangan Abdul Mukti Ali dalam menciptakan kestabilan nasional sehingga pembangunan nasional dapat berjalan lancar adalah konsep beliau untuk mencapai kerukunan hidup antarumat beragama. Konsep itu dikenal luas yakni agree in disagreement, yang biasa diartikan setuju dalam perbedaan. Mengenai pengertian konsep ini, Abdul Mukti Ali menguraikan lebih lanjut sebagai berikut:

"Bangsa Indonesia yang kini sedang membangun menuju manusia seutuhnya dalam "Plural Society" masyarakat serbaganda, baik keyakinannya, agamanya, bahasa dan budayanya. Manusia Indonesia yang beragama ini dituntut supaya rukun dalam kehidupan agama. Keributan dalam kehidupan agama merupakan halangan bagi pembangunan. Pembangunan mustahil dilaksanakan dalam masyarakat yang kacau balau. Kerukunan hidup masyarakat merupakan pra-kondisi bagi pembangunan. Rukun dalam kehidupan agama dapat tercipta apabila tiap-tiap orang itu saling tegang menegangkan rasa dan lapang dada (toleran)" (Abdul Mukti Ali, 1976:20).

Bangsa Indonesia lahir dari sebuah perjalanan panjang dan unik. Bangsa ini terhimpun dari berbagai ras, berbagai budaya lokal, adat istiadat, agama yang beragama, yang semuanya secara alamiah mengandung perbedaan. Namun dalam realita perjalanan sejarah pembentukan bangsa Indonesia, berbagai perbedaan yang ada tidak menyurutkan dan menjadi penghalang untuk bersatu. Salah satu ajakan menarik memperkuat soliditas keindonesiaan kita adalah membumikan empat pilar kehidupan berbangsa, yakni, Pancasila, UUD 1945, NKRI dan Bhinneka Tunggal Ika, merupakan khazanah sekaligus modalitas bangsa Indonesia.

Landasan untuk membina kerukunan hidup umat beragama di Indonesia menurut Abdul Mukti Ali ada dua; Pertama adalah bersifat filosofis berupa falsafah negara Pancasila yang mengundang nilai-nilai dan prinsip-prinsip dasar yang dapat diterima oleh semua pihak dan golongan. Kedua adalah bersifat pragmatis, yakni tugas nasional dalam rangka pembangunan bangsa di mana semua pihak berkewajiban melaksanakan dan menyukseskannya. Sebagaimana diketahui, bangsa Indonesia terdiri dari beranekaragam suku, budaya, bahasa, agama, tingkat pendidikan, kehidupan ekonomi, dan lain sebagainya. pluralitas tersebut, bisa menjadi potens yang positif manakala menjadi motivasi untuk bersaing yang sehat dalam rangka memperoleh kemajuan. Namun sebaliknya pluralitas menjadi negatif manakala berubah menjadi potensi yang bisa menyulut pertentangan serta permusuhan yang saling menghancurkan.

Jika para penganut agama lebih memilih jalan kekerasan dan watak konservatisme, maka pilihan itu akan membuahkan sikap permusuhan, malapetaka, dan menutup terciptanya dialog. Oleh karena itu, dialog yang humanis dan terbuka yang dibangun di atas dasar keluasan pandangan merupakan sesuatu yang mendesak. Maka menurut Abdul Mukti Ali, semua agama tidak hanya didesak untuk memikirkan sikap praktis untuk bergaul dengan agama lain, tetapi juga didesak untuk memahami secara teologis apakah makna kehadiran agama-agama dan kepercayaankepercayaan yang lain itu. Karena dialog merupakan wadah perjumpaan antar sesama 
anak manusia yang dapat mencairkan berbagai sikap keras dan menghilangkan sikap saling mencurigai antar sesama umat beragama. Orang yang anti dialog dalam konteks kehidupan saat ini seperti orang yang ingin memikul beban berat sendirian, padahal beban itu menjadi ringan jika dijinjing secara bersamasama. Kehidupan manusia senantiasa memperlihatkan pluralitas dan kemajemukannya, khususnya dari sudut agama.

Kemesraan dalam membangun kerjasama seperti ini tidak terlepas dari sikap tulus dalam beragama. Sikap itu menghendaki setiap penganut agama memberikan yang terbaik bagi kemanusiaan tanpa berharap imbalan. Bisa saja seorang penganut agama dengan penganut agama lain memiliki ikatan emosional yang begitu dalam, faktor utamanya adalah ketulusan. Perbedaan iman bukan merupakan tembok penghalang bagi bertautnya dua hati anak manusia yang berbeda kayakinan. Karena itu, tanpa ketulusan beragama itu, kerjasama yang dibangun oleh para penganut agama akan terasa kering dan berada pada tataran fisikal saja.

Untuk itu, dirasa perlu untuk mengadopsi serta mengaplikasikan konsep tersebut dalam rangka menciptakan kestabilan nasional dapat berjalan lancar melalui kerukunan hidup umat beragama. Karena sulit bagi bangsa Indonesia melaksanakan program pembangunan dalam rangka memperolah kehidupan yang sejahtera, kalau kondisi kerukunan antarumat beragama belum terpelihara. Karena itu, prinsip agree in disagreement, dialog antaragama, serta urgensi disiplin ilmu perbandingan agama, merupakan perwujudan semangat Bhinneka Tunggal Ika dalam rangka mewujudkan kerukunan hidup umat beragama di negara Indonesia.

\section{Implikasi Pendidikan Islam Abdul Mukti Ali terhadap Pendidikan di Indonesia}

\section{Abdul Mukti Ali Ketika menjadi Menteri Agama}

Ketika Abdul Mukti Ali memimpin Departemen Agama, posisi jabatan pemerintahan sudah sangat mapan di dalam struktur pemerintahan Republik Indonesia. Boleh dikatakan, hampir tidak ada lagi kalangan masyarakat di Indonesia yang mempertanyakan, apalagi meragukan, kehadiran dan fungsi Departemen Agama. Struktur organisasi yang juga sudah lengkap dan pada batas-batas tertentu, dianggap memiliki kepentingan-kepentingan seluruh komunitas beragama. Semenjak langkah reorganisasi yang diprakarsai oleh K.H. Wahid Hasyim, menteri agama pada pemerintahan RIS dan kabinet Natsir (1949-1953 M), dan berlanjut hingga K.H. Mohammad Dachlan, susunan organisasi Departemen Agama terus mengalami perubahan dan penambahan. Hal ini terjadi karena desakan-desakan politik yang mempertanyakan fungsi departemen yang secara khusus mengatur masalah-masalah keagamaan. Suatu proses panjang yang menjadikan Departemen Agama berada pada posisi sulit untuk sekian lama.

Dalam hal ini, prestasi utama Abdul Mukti Ali terletak pada peran yang ia mainkan dalam reorientasi politik kebijakan Departemen Agama dengan membangkitkan kegairahan kehidupan beragama dan memperbaiki citra lembagalembaga keagamaan. Pada saat yang bersamaan, kebijakan tersebut dibarengi dengan kebijakan menumbuhkan keharmonisan hubungan antar umat beragama, khususnya antara muslim dan Kristen di Indonesia.

Secara garis besar, kerangka kebijakan keagamaan Abdul Mukti Ali mengikuti keyakinannya pada posisi agama dalam Pancasila dan peran agama di dalam agenda modernisasi Orde Baru. Dasar negara Pancasila, yang lahir bersamaan dengan UUD 1945, merupakan suatu bentuk upaya politik dalam mencari landasan persatuan dari seluruh komunitas-komunitas agama seperti Muslim, Kristen, Khatolik, Hindu dan Budha. Sehingga terciptalah suatu basis ideologi politik yang dapat diterima semua pihak yang mengambil bentuk otoritas Negara Non Theokrasi. Dengan demikian, menurut Abdul Mukti Ali diasumsikan adanya suatu sistem pemerintahan dengan bentuk kekuasaan yang memisahkan antara otoritas politik dengan otoritas agama. Tetapi, pada sisi lain, pemerintah turut bertanggung jawab dalam mendukung dan membina kehidupan agama masyarakat. Negara Pancasila, dengan demikian, mengakui 


\section{Kalpataru, Volume 7, Nomor 2, Desember 2021 (142-152)}

kewenangan Departemen Agama dan kebijakan-kebijakan keagamaan sebagai bagian yang integral dari kebijakan politik pemerintahan.

Karakteristik ideologi negara semacam itu oleh Abdul Mukti Ali dipandang sebagai basis legitimasi bagi agenda modernisasi politik Orde Baru. Bagi Abdul Mukti Ali, pemerintahan Orde Baru membagi kegiatan keagamaan ke dalam dua bentuk, disatu sisi bersifat agama dan di sisi lain bersifat politis. Terhadap yang pertama, pemerintah membolehkan dan bahkan mendukung. Segala bentuk kegiatan masyarakat yang berkaitan dengan peningkatan penghayatan terhadap agama. Namun demikian, pemerintah menghindari segala bentuk kegiatan keagamaan yang menyadarkan atau cenderung untuk perjuangan politis. Atas dasar inilah, dalam sebuah seminar di Malang pada 1972, Abdul Mukti Ali menegaskan bahwa, "Itulah suatu aspirasi dan pilihan politik yang saya percaya akan memperbaiki hubungan antara Islam dan negara di Indonesia".

Dengan latar belakang politik semacam itu dan didukung oleh massa Islam yang secara ideologis masih kuat. Elit muslim menyampaikan beberapa harapan terhadap presiden Soeharto. Harapan itu sendiri sebenarnya bermuatan politis. Namun, karena coraknya yang terlalu ideologis dan subtansinya mengarah pada ideologi Islam, banyak kalangan memandang bahwa harapan itu menampakkan sisa-sisa aspirasi ideologis umat Islam untuk tetap memperjuangkan berdirinya Negara Islam di Indonesia. Pertama, rehabilitasi partai Masyumi oleh pemerintah. Kedua, pemberian status resmi terhadap Piagam Jakarta dalam Pancasila. Dan ketiga, pelaksanaan pemilu secara demokratis dengan menggunakan sistem multi partai secepatnya.

Bagi Abdul Mukti Ali, kekalahan partaipartai Islam itu memang sudah diramalkan. Berbagai bentuk aspirasi Islam ideologis untuk membangun suatu partai yang secara politis tangguh juga terbukti tidak pernah menarik sebagian besar kalangan masyarakat. Kendatipun demikian, fenomena politik dan pergaulan pemikiran keagamaan yang terjadi menyadarkan bahwa, hingga masa itu, partaipartai politik Islam dan umat Islam umumnya masih mendambakan terbentuknya Indonesia sebagai "Negara yang berdasarkan Islam" atau negara di mana hukum-hukum berlandaskan pada Al-Qur'an dan Hadist. Bahkan, partaipartai Islam juga berpandangan, jika Indonesia tidak berada di bawah pemerintahan partai Islam, negara ini akan menjadi negara sekuler.

Dalam konteks inilah, semenjak periode awal jabatannya Abdul Mukti Ali memberikan perhatian yang besar terhadap upaya untuk mendekatkan hubungan umat Islam dengan pemerintahan Orde Baru. Kepada para ulama dan politisi muslim, Abdul Mukti Ali meyakinkan adanya iktikad baik pemerintah Orde Baru untuk membina kehidupan beragama. Pemerintah, dalam hal ini Departemen Agama akan memberikan keluasan, bahkan membantu umat Islam mengerjakan semua kewajiban agama. salah satu sikap politik yang dimaksudkan untuk tujuan tersebut adalah ketika Abdul Mukti Ali menyampaikan pernyataan dalam sebuah seminar di Malang tahun 1972; sebuah elaborasi yang tersaring dari konsep kenegaraan yang diharapkan cocok dengan kultur masyarakat religious Indonesia, khususnya Islam.

\section{Kritik Kebijakan Departeman Agama pada masa Abdul Mukti Ali}

Kebijakan Departemen Agama pada masa Abdul Mukti Ali tidak semua berdampak baik terhadap Lembaga Pendidikan Islam, penulis teringat pada sejarah berdirinya Madrasah Tsanawiyah Negeri (MTsN) atau Madrasah Aliah Negeri (MAN) yang pada awalnya tidak disukai oleh masyarakat kala itu, bermula pada tahun 1950, berdasarkan Surat Edaran Menag 15/8/1950, dibentuklah Sekolah Guru Agama Islam (SGAI) sebagai solusi untuk membentuk guru agama yang akan disebarkan ke berbagai wilayah di Indonesia, masa belajar di SGAI adalah 5 tahun. Di tahun 1951, SGAI beralih ke PGA (Pendidikan Guru Agama) berdasarkan Surat Pemerinah Menag No. 7 Tahun 1950/15 Desember 1951, dengan masa belajar 3 tahun sesudah tamat SD dan diadakan program PGAP 4 tahun kelas I-IV dan PGAA kelas V-VI dan 2 tahun Tamat SMP. Pada tahun 1954, menjadi PGAN dengan lama belajar 4 tahun, setelah Sekolah Dasar atau MI. Pada 
tahun 1959 berdasarkan Surat Perintah Menag No. 18 Tahun 1959, tanggal 29 April 1959 ditetapkan Nama Sekolah Dinas Guru Agama, dengan rincian masa belajar adalah sebagai berikut: PGAN 4 tahun (Kelas I s.d. IV), PGAN 6 tahun (Kelas I s.d. VI).

Pada Tahun 1978 berdasarkan SK Menag No. 19 Tahun 1978, tanggal 1 Januari 1978, terjadi perubahan dari PGAN 6 tahun menjadi PGAN kelas IV sampai dengan kelas VI dan MTsN untuk kelas I sampai dengan III. Perubahan yang dilakukan oleh Menteri Agama Abdul Mukti Ali ini berdampak besar terhadap Institusi Pendidikan Islam yang berada pada naungan Departemen Agama. Masyarakat yang sebelumnya tertarik menyekolahkan anaknya di Lembaga Pendidikan Islam beralih ke Lembaga Pendidikan Umum. Hal ini berakibat pada menyusutnya jumlah peserta didik tersebut.

Pada tanggal 25 April 1990, berdasarkan Surat Keputusan Menteri Agama No. 64 Tahun 1990, tentang Alih Fungsi Pendidikan Guru Agama Negeri menjadi MAN atas nama Menteri H. Munawir Sjadzali, PGAN berubah fungsi menjadi Madrasah Aliyah Negeri, sejajar dengan Sekolah Menengah Atas hingga sekarang.

\section{SIMPULAN}

1. Konsep pemikiran pendidikan Abdul Mukti Ali dapat disimpulkan bahwa peran agama dalam pendidikan menjadi bagian teratas untuk pembangunan Indonesia. Dalam memahami agama Abdul Mukti Ali juga mencetuskan ilmu metodologi agama yang berusaha menghubungkan tujuan dibentuknya manusia yaitu sebagai hamba dan pemimpin dengan tujuan pendidikan.

2. Kontribusi pemikiran Abdul Mukti Ali dalam menegakkan kerukunan antarumat beragama di Indonesia, menyentuh dua aspek, yakni aspek keilmuan dan relasi sosial. Pada aspek keilmuan ditandai dengan tampilnya Perbandingan Agama sebagai ilmu pengetahuan yang begitu penting untuk memahami dan menyikapi keragaman agama.

3. Abdul Mukti Ali menjadi menteri pada masa Orde Baru yaitu pada Kabinet Pembangunan II dengan transisi waktu 28
Maret 1973 sampai 29 Maret 1978. Pada masa itu, banyak perubahan yang telah dilakukan dan itu memberikan dampak besar terhadap pendewasaan berfikir masyarakat Indonesia. Langkah konkrit yang dilakukan adalah memodernisasi lembaga Departemen Agama dengan mengusung jargon pengembangan manusia seutuhnya.

\section{DAFTAR PUSTAKA}

Abuddin Nata. 2012. Pemikiran Pendidikan Islam dan Barat. Jakarta: PT Raja Grafindo Persada.

Abdul Mukti Ali. 1976. Agama dan Pembangunan di Indonesia. Jakarta: Biro Hukum dan Hubungan Masyarakat Departemen Agama RI. 1991. Metode Memahami Agama Islam. Jakarta: Bulan Bintang. 1996. Ilmu Perbandingan Agama di Indonesia. Bandung: Mizan. 1998. Agama Dalam Wacana Pergumulan Masyarakat Kontemporer. Yogyakarta: PT Tiara Wacana.

Oemar Malik. 2011. Kurikulum dan Pembelajaran. Jakarta: Bumi Aksara.

Masdar Hilmi, 2005. Studi Islam, Dinamika Baru. Surabaya: Arkola.

M. Roqib. 2009. IImu Pendidikan Islam Pengembangan Pendidikan Integratif di Sekolah, Keluarga dan Masyarakat. Yogyakarta: LKIS.

Singgih Basuki, 2013. Pemikiran Keagamaan Abdul Mukti Ali. Yogyakarta: Suka Press.

Sugiyono. 2017. Metode Penelitian Kuantitatif, Kualitatif, dan R\&D. Bandung: Alfabeta.

Sugiyono. 2012. Metode Penelitian Kuantitatif Kualitatif dan R\&B. Bandung: Alfabeta.

T, A. M., \& Purwoko, B. (2017). Studi Kepustakaan Mengenai Landasan Teori dan Praktik Konseling Expressive Writing. Bimbingan dan Konseling, Fakultas IImu Pendidikan, Universitas Negeri Surabaya, 1-8. 


\section{KETENTUAN PENULISAN ARTIKEL JURNAL KALPATARU}

1. Naskah berbahasa Indonesia yang disempurnakan bertemakan kesejarah yang meliputi hasil penelitian sejarah, pengajaran sejarah dan penelitian kebudayaan.

2. Naskah harus asli dan belum pernah dimuat dalam media lain. Naskah dapat berupa hasil penelitian/artikel kajian konseptual yang ditulis oleh perorangan dan atau kelompok.

3. Naskah ditulis dengan cara-cara yang sesuai dengan ketentuan penulisan artikel ilmiah menggunakan bahasa Indonesia yang baku, berupa ketikan, beserta soft file dalam CD-RW atau dengan mengirimkan email pada redaksi jurnal Kalpataru dengan alamat jurnalkalpatarusejarah@gmail.com, spasi tunggal, jenis huruf arial narrow ukuran 12, dengan panjang naskah antara 8-15 halaman pada kertas A4.

4. Artikel hasil penelitian memuat:

JUDUL

Nama Penulis

Abstrak
: XXX (HURUF KAPITAL)

: (disertai jabatan, institusi, dan email)

: (Bahasa Indonesia yang memuat 100-200 kata diikuti kata kunci, dengan jenis huruf arrial narrow dan ukuran huruf 11 serta dicetak miring).

: (memuat latar belakang masalah, tinjauan pustaka secara ringkas, masalah penelitian, dan tujuan penelitian).

B. METODE PENELITIAN

C. HASIL DAN PEMBAHASAN

D. SIMPULAN : (berisi simpulan).

DAFTAR PUSTAKA : (berisi pustaka yang dirujuk dalam uraian naskah).

5. Artikel Kajian Konseptual memuat:

\section{JUDUL \\ Nama Penulis \\ Abstrak}

PENDAHULUAN

Sub Judul

Simpulan

DAFTAR PUSTAKA
: XXX (HURUF KAPITAL)

: (disertai jabatan, institusi, dan email)

: (Bahasa Indonesia yang memuat 100-200 kata diikuti kata kunci, dengan jenis huruf arrial narrow dan ukuran huruf 11 serta dicetak miring.

: (memuat latar belakang masalah, tinjauan pustaka secara ringkas, masalah penelitian, dan tujuan penelitian).

: Sesuai dengan kebutuhan (tanpa numbering).

: (berisi simpulan dan saran).

6. Referensi sumber dalam teks artikel ditulis dengan menggunakan side note, contoh (Jalaludin, 1991:79); sementara penulisan daftar pustaka disusun dengan ketentuan. Nama pengarang. Tahun terbit. Judul (dicetak miring). Kota terbit: Nama Penerbit. Contoh: Koentjaraningrat. 2010. Manusia dan Kebudayaan di Indonesia. Jakarta: Djambatan. Daftar pustaka hanya memuat pustaka/sumber yang dirujuk dalam uraian dan disusun menurut abjad tanpa nomor urut.

7. Naskah yang dimuat akan disunting kembali oleh redaksi tanpa mengubah isinya.

8. Naskah yang ditolak (tidak bisa dimuat) akan dikirim kembali ke penulis dengan pemberitahuan tertulis dari redaksi atau melalui email.

9. Penulis yang naskahnya dimuat akan mendapat 1 (satu) majalah nomor yang bersangkutan.

10.Kontak person: Muhamad Idris (081271498618); Eva Dina Chairunisa (082281267851); Jeki Sepriady (085269261780). 